\title{
LANDASAN QUR'ANI TENTANG ZIKIR DALAM AJARAN TAREKAT
}

\author{
Ecep Ismail
}

\begin{abstract}
ABSTRAK
Inti ajaran yang dikembangkan dalam tarekat selalu berlandaskan Alquran meskipun harus melalui proses penafsiran yang dipaksakan seperti dalam ajaran zikir. Ada tiga jenis orang yang berzikir, yaitu: Orang yang berzikir kepada Allah dengan lisannya sedang hatinya lalai; Orang yang lain berzikir kepada-Nya dengan lisan disertai dengan hadirnya hati;dan yang ketiga adalah orang yang berzikir kepada Allah dengan hatinya sedangkan lisannya tidak mengucapkan apa pun. Diantara ayat al-Qur 'an yang dijadikan landasan zikir dalam ajaran tarekat adalah: QS 33:4142, QS. 3:191, QS.29:45, QS 2:152, QS 59:19, QS 43: 36, dan QS 58:19.
\end{abstract}

\section{KATA KUNCI}

Tasawuf; Tarekat; Bai'at; Zikir

DOI: https://doi.org/10.15575/saq.v1i2.1434

\section{A. PENDAHULUAN}

Dalam tradisi tasawuf, Nabi Muhammad saw. dan para sahabat adalah teladan pertama dalam silsilah spiritual, yang kemudian diteruskan oleh para guru sufi. Mereka adalah pewaris tradisi dan pembawa berkah yang dipindahkan dari generasi ke generasi. Perannya tersebut membuat dia menjadi pusat secara lahir dan menjadi pusat secara batin.

Di dalam ilmu tasawuf, istilah tarekat tidak hanya ditujukan pada aturan atau cara-cara tertentu yang digunakan oleh seorang syaikh tarekat dan bukan pula terhadap kelompok yang menjadi pengikut salah seorang syaikh tarekat, tetapi meliputi segala aspek ajaran yang ada di dalam agama Islam, seperti shalat, puasa, zakat, haji dan sebagainya yang dirangkum dalam istilah zikir, yang semuanya itu merupakan jalan atau cara mendekatkan diri kepada Allah. Maskipun dalam tarekat yang sudah melembaga itu semua ditambah dengan pengamalan lain melalui tuntunan dan bimbingan seorang syaikh melalui bai'at.
Pada kenyataannya inti ajaran yang dikembangkan dalam tarekat tetap berlandaskan Alquran meskipun harus melalui proses penafsiran yang dipaksakan seperti dalam ajaran zikir dan bai'at.

\section{B. PENGERTIAN DAN TUJUAN TAREKAT}

Tarekat berasal dari bahasa Arab thariqah, jamaknya tharaiq, yang berarti: (1) jalan atau petunjuk jalan atau cara, (2) metode, sistem (aluslub), (3) mazhab, aliran, haluan (al-mazhab), (4) keadaan (al-halah), (5) tiang tempat berteduh, tongkat, payung ('amud almizalah). ${ }^{1}$

Menurut Al-Jurjani 'Ali bin Muhammad bin 'Ali (740-816 M), tarekat ialah metode khusus yang dipakai oleh salik (para penempuh jalan) menuju Allah melalui tahapantahapan/maqamat.

Tarekat, menurut sebagian sufi adalah istilah bagi paket-paket zikir berdasarkan model

\footnotetext{
1 “Wikipedia Indonesia," t.t.
} 
kurikulum pembelajaran. ${ }^{2}$ Dalam kitab Jami 'ul Ushul fil Auliya' karya Syaikh Ahmad AlKamisykhonawi An-Naqsyabandi disebutkan, "Tarekat adalah laku tertentu bagi orang-orang yang menempuh jalan kepada Allah, berupa memutus/meninggalkan tempat-tempat hunian dan naik ke maqam-maqam/tempat-tempat mulia." ${ }^{3}$ Tarekat juga merupakan himpunan tugas-tugas perbaikan temporal-kondisional yang didasarkan pada pokok-pokok latihan pembelajaran yang dijadikan sebagai media untuk mencapai kesucian jiwa dan kedamaian kalbu, yaitu kesucian jiwa dari berbagai kotoran dan penolakan terhadap penyakitpenyakit hati. ${ }^{4}$ Di sisi lain ada yang mengartikan tarekat adalah ilmu untuk mengetahui hal ihwalnya nafsu dan sifatsifatnya, mana yang tercela kemudian dijauhi dan ditinggalkan, dan mana yang terpuji kemudian diamalkan. ${ }^{5}$ Kemudian Tarekat juga diartikan sebagai jalan yang ditempuh para sufi, dan digambarkan sebagai jalan yang berpangkal pada syari'at, sebab jalan utama disebut syar' sedangkan anak jalan disebut thariq. ${ }^{6}$ Kata turunan ini menujukkan bahwa menurut anggapan para sufi, pendidikan mistik merupakan cabang dari jalan utama yang terdiri dari hukum Ilahi, tempat berpijak bagi setiap Muslim. Oleh karena itu, tak mungkin ada jalan

${ }^{2}$ Sayyid Nur bin Sayyid Ali, Tasawuf Syar'i, Kritik atas Kritik (Jakarta: Penerbit Hikmah, 2003), 135.

${ }^{3}$ Agus Yahya dan M. Nawawi Syafi'i, ed., Mengenal Thariqah; Panduan Pemula Untuk Mengenal Jalan Menuju Allah (Semarang: , Sekretariat Jenderal Idarah Aliyah Jam'iyyah Ahli Al Thariqah Al-Mu'tabarah AnNahdliyyah bekerjasam dengan C.V. Bina Ilmu, 2005), 1 .

${ }^{4}$ Sayyid Nur bin Sayyid Ali, Ibid, hlm. 135.

${ }^{5}$ Agus Yahya dan M. Nawawi Syafi'i (ed.), Op.Cit., hlm. 1.

${ }^{6}$ Annemarie Schimmel, Op. Cit., hlm. 123.

${ }^{7}$ Qutbatin al-'Ibadi, At-Tasfufa fi ahwal as-Sufiya, or Sufiname, ed. Ghulam Muhammad Yusufi (Teheran, 1347 H/1968), hlm.15, dalam Annemarie Schimmel, Ibid, hlm. 123.

8 Zawiyah atau sawiya arti harfiahnya "pojok", dipakai sebagai istilah bagi pusat-pusat kecil, seperti misalnya tempat tinggal seorang Syaikh yang terpencil, Annemarie Schimmel, Op.Cit., 294.

${ }^{9}$ Ribath adalah pusat jamaah. Namun, pada dasarnya dihubungkan dengan benteng-benteng perbatasan para tanpa adanya jalan utama tempat ia berpangkal; pengalaman mistik tak mungkin didapat bila perintah syari'at yang mengikat itu tidak ditaati terlebih dahulu dengan seksama. ${ }^{7}$ Akan tetapi, tariq atau jalan itu lebih sempit dan lebih sulit dijalani serta membawa santri - disebut salik atau pengembara - dalam suluk atau pengembaraannya melalui berbagai persinggahan (maqam), sampai mungkin cepat atau lambat akhirnya mencapai tujuannya, yaitu tauhid yang sempurna; yaitu pengakuan berdasarkan pengalaman bahwa Tuhan adalah Satu.

Dengan demikian, dilihat dari paparan di atas tarekat memiliki dua pengertian, pertama ia berarti metode pemberian bimbingan spiritual kepada individu dalam mengarahkan kehidupannya menuju kedekatan diri dengan Tuhan. Kedua, tarekat sebagai persaudaraan kaum sufi yang ditandai dengan adanya lembaga formal seperti zawiyah, ${ }^{8}$ ribath,${ }^{9}$ atau khanaqah. ${ }^{10}$ Bila ditinjau dari sisi lain tarekat itu mempunyai tiga sistem, yaitu: sistem kerahasiaan, sistem kekerabatan (persaudaraan) dan sistem hirarki seperti khalifah tawajjuh atau khalifah suluk, ${ }^{11}$ syaikh atau mursyid, wali ${ }^{12}$ atau qutub. ${ }^{13}$ Kedudukan guru tarekat diperkokoh dengan ajaran wasilah dan silsilah. Keyakinan berwasilah dengan

tentara Islam dan memperluasnya, Annemarie Schimmel, Ibid, hlm. 294.

10 Khanaqah adalah pusat-pusat kebudayaan dan teologi para sufi, Annemarie Schimmel, Ibid, hlm. 294.

${ }^{11}$ Khalifah tawajjuh atau khalifah suluk adalah

12 Wali biasa diterjemahkan menjadi "orang kudus", wali, berarti "seseorang di bawah perlindungan khusus, teman,"; atribut inilah yang paling utama. Seperti keterangan Qusyairi, kata itu bersifat aktif dan pasif: seorang wali adalah seorang yang urusannya dituntut (tuwuliyya) oleh Tuhan dan melakukan (tawalla) pemujaan dan kepatuhan, Annemarie Schimmel, Ibid, hlm. 253.

${ }^{13}$ Qutub adalah pusat yang sesungguhnya dari daya rohani, dan kesejahteraan dunia ini tergantung kepada pusat itu. Qutub terletak dalam kesenyapan yang sempurna, dasarnya pada Tuhan - maka dari itulah mengapa semua "bintang-bintang yang lebih kecil" beredar di sekelilingnya, Annemarie Schimmel, Ibid, hlm. 254. 
guru dipererat dengan kepercayaan karamah, barakah atau syafa'ah atau limpahan pertolongan dari guru.

\section{TAREKAT MUKTABARAH DAN GHAIR MUKTABARAH}

Tarekat dibagi ke dalam dua kategori, tarekat mu'tabarah dan ghair mu'tabarah. Diadakannya pembedaan ini bertujuan untuk membedakan tarekat dengan aliran kebatinan dan gerakan mistisisme sinkretik lainnya, yang tak termasuk Ahl Al-Sunnah wa Al Jama'ah, serta tarekat-tarekat lokal semacam Wahidiyah, yang termasuk tapi tidak mempunyai silsilah yang jelas ${ }^{14}$.

Tarekat yang merasa kelompoknya masuk dalam kategori mu'tabarah mendirikan sebuah lembaga yang bernama Jam'iyyah Ahl- AlThariqah Al-Mu'tabarah. Perkumpulan ini didirikan pada tahun 1957 oleh sejumlah kiai tarekat senior yang semuanya berafiliasi dengan Nahdhatul Ulama. Tujuannya memersatukan semua tarekat yang bonafide (mu'tabar) demi mempertahankan kepentingan bersama.

Kata mu'tabar maksudnya bahwa tarekat bersangkutan mengindahkan syari'at dan termasuk Ahl Al-Sunnah wa Al-Jama'ah, dan mempunyai silsilah yang sah, yaitu berkesinambungan sampai Nabi sendiri. Nabi Muhammad dari Jibril dan Jibril dari Allah swt. Sedangkan yang dimaksud dengan ghair mu'tabarah adalah tarekat yang tidak masuk kategori tadi. ${ }^{15}$ Jam'iyyah telah menentukan daftar nama tarekat yang dianggapnya mu'tabar' ${ }^{16}$.

${ }^{14}$ Ibid, hlm. 179.

15 Menurut Rais 'Am Jam'iyyah Ahli Al Thariqah Al Mu'tabarah An-Nahdhiyah, Al Habib Muhammad Luthfi bin Ali bin Hasyim bin Yahya ada 43 aliran tarekat, yaitu: 1. 'Abbasiyah, 2. Ahmadiyah, 3. Akbariyah, 4. 'Alawiyah, 5. Baerumiyah, 6. Bakdasiyah, 7. Bakri-yah, 8. Bayumiyah, 9. Buhuriyah, 10. Dasuqiyah, 11. Ghoibiyah, 12. Ghozaliyah, 13. Haddadiyah, 14. Hamzawiyah, 15. Idrisiyah, 16. 'Idrusiyah, 17. 'Isawiyah, 18. Jalwatiyah, 19. Justiyah, 20. Kal-syaniyah, 21. Khodliriyah, 22. Kholwatiyah, 23. Kholidiyah wan-Naqsyabandiyah, 24. Kubrowiyah, 25. Madbuliyah, 26. Malamiyah, 27. Maulawiyah, 28. Qodiriyah

\section{BAI'AT}

Permulaan seseorang memasuki tarekat adalah melalui bai'at, yaitu mengikat janji atau sumpah setia dengan khalifah atau mursyid. Orang itu masih awam tentang pengetahuan tasawuf, maka khalifah mulai mengantarkannya dengan ucapan dua kalimat syahadat secara ikhlas. Dalam kesempatan bai'at itu, khalifah menyampaikan rahasia suluk antara khalifah - murid dengan suatu pola hubungan persahabatan yang berdasar dari ajaran-ajaran tarekat. Bagi pemula, melalui bai'at itu sudah harus membatasi diri dari kebebasannya bersikap dan bertindak seperti sebelumnya, karena ia kini sudah melalui satu jalan guna memproses diri mendekatkan diri pada Allah swt.

Bai'at (pernyataan setia) dalam tradisi sufi adalah istilah bagi penampakan keterkaitan sang murid kepada syaikh/mursyid dalam rantai bimbingan, penyucian dan memperoleh derajat ihsan. ${ }^{17}$ Bai' at merupakan kepercayaan suci, kepercayaan yang diberikan seorang Mursyid kepada muridnya, dan demikian sebaliknya. Bai'at bagi seorang Mursyid bermakna ganda: kepercayaan yang diberikan guru kepada murid, dan kepercayaan yang diberikan murid kepada Mursyid. ${ }^{18}$

Sesudah menyampaikan nasihat ini, sembari memegangi tangan sang murid, syaikh membaca Alquran: a) Surah al-Fatihah; b) Surah Yunus; c) Surah al-fath (ayat 1-10); Surah al Ahzab (ayat 56); Surah ash-Shaffat (ayat 180-182). Kemudian syaikh memohon ampunan (istighfar) kepada Allah:

Upacara bai'at dilakukan dengan cara yang berbeda seperti berikut ini: ${ }^{19}$ Jika seorang murid ingin bergabung dengan sebuah tarekat

wan-Naqsyabandiyah, 29. Rifa'iyah, 30. Rumiyah, 31. Sa'diyah, 32. Samaniyah, 33. Sumbuliyah, 34. Sya'baniyah, 35. Syadzaliyah, 36. Syathoriyah, 37. Syuhrowiyah, 38. Tijaniyah, 39. 'Umariyah, 40. 'Usyaqiyah, 41. 'Utsmaniyah, 42. Uwaisiyah dan 43. Zainiyah. Agus Yahya dan M. Nawawi Syafi'i(ed.), Op. Cit., hlm.11.

${ }^{16}$ Martin Van Bruinessen, Op.Cit., hal. 179.

${ }^{17}$ Sayyid Nur bin Sayyid Ali, Op.Cit., hlm. 163.

18 Hazrat Inayat Khan, Kehidupan Spiritual, Tiga Esai Klasik tentang Kehidupann Ruhani, Pustaka Sufi, Yogyakarta, 2002, hlm. 114.

${ }^{19}$ Ibid, hlm. 282-283. 
sufi, maka ia pun diterima di dalam sebuah majelis. Lalu, Syaikh menyentuh tangannya dan membisikkan ke telinganya kalimat $L \hat{a}$ ilâha illâllâh (Tiada tuhan selain Allah)tiga kali, dan kemudian memerintahkan agar sang murid mengulanginya 101, 151, atau 301 kali setiap hari. Sang murid berjanji untuk menghabiskan waktunya dalam menyendiri (khalwat) dan mengulangi berbagai manifestasi (musyahidah)-nya kepada syaikh. Sesuai dengan musyahidah ini, syaikh mengetahui kapan ia membisikkan berturut-turut kata berikut ini: a) Yâ Allâh (Wahai Allah); b) Yâ Hô (Wahai Dia); c) Yâ Haqq (Wahai Yang Maha Benar); d) Yâ Hayy (Wahai Yang Maha Hidup); e) Yâ Qayyûm (Wahai Yang Maha Berdiri Sendiri); f) Yâ Qahhâr (Wahai Yang Maha Memaksa).

\section{E. ZIKIR}

Zikir, ritual ini terdiri dari doa dan wirid berulang yang terkadang cepat dan sederhana, dengan menyebut satu nama Allah. Zikir adalah mengingat atau mengenang Tuhan, yang dapat dilakukan dengan diam-diam atau bersuara. ${ }^{20}$ Kadang-kadang zikir lebih mendetail dan mendalam. Zikir sering dilaksanakan sampai kesadaran pelaku hilang atau dia pingsan karena kelelahan. Zikir bermanfaat untuk mengosongkan kesadaran dari semua kepedulian dan pemikiran tentang kehidupan manusia dan berkonsentrasi pada Allah, firman dan hukum-Nya, atau Nabi Muhammad. Zikir adalah langkah pertama di jalan cinta; sebab kalau kita mencintai seseorang, kita suka menyebut namanya dan selalu ingat kepadanya. ${ }^{21}$ Oleh sebab itu, siapa pun yang dalam hatinya telah tertanam cinta akan Tuhan, di situlah tempat kediaman zikir yang terus menerus.

Salah satu persoalan penting, paling tidak semua ahli menyepakatinya, ada tiga tingkatan

\footnotetext{
${ }^{20}$ Annemarie Schimmel, Op.Cit., hlm. 212.

21 Ibid, hlm. 213.

${ }^{22}$ Leonard Lewishon (ed.), Buku Pertama, Warisan Sufi, Sufisme Persia Klasik dari Permulaan hingga Rumi (700-1300), terj. Pustaka Sufi, Yogyakarta, 2002, hlm.
} 610. penguasaan dalam zikir. Pertama, zikir diucapkan dengan lisan; kemudian seseorang haruslah menuju tingkatan yang lebih dalam, yakni zikir dalam hati; tetapi kesempurnaan yang dikehendaki adalah zikir yang tertanam kuat sehingga diucapkan secara otomatis kapan saja di dalam hati, di dalam lisan. Zikir tersebut menjadi amalan sebagaimana yang telah dijelaskan oleh Abu Qasim al-Qusyayri - yakni zikir dengan seluruh tubuh. ${ }^{22}$ Gagasan tentang tiga tingkatan dalam zikir telah ditetapkan dengan berbagai variasi. Menurut kitab Sufisme lama, yakni Kitab al-Luma' ditulis oleh Abu Nasr as-Sarraj, menyatakan ${ }^{23}$ bahwa beliau mendengar Ibnu Salim berkata ketika ditanya tentang zikir, "Zikir itu ada tiga macam: zikir dengan lisan, ia adalah amal shaleh yang pahalanya dilipatgandakan sepuluh kali; zikir dengan hati, yang pahalanya dilipatkan tujuh ratus kali; dan zikir yang pahalanya tidak dapat ditimbang atau dihitung, yakni zikir yang dibarengi perasaan cinta dan malu (hay $\bar{a}$ ') karena kedekatannya (dengan Allah).

Sufi yang sezaman dengan Sarraj, Abu Bakar al-Kalabazi (w. 385/995) dari Bukhara, dalam "kitab sahih tentang ajaran sufi, memberikan tiga ajaran lainnya tentang zikir. ${ }^{24}$ Menurutnya, jenis zikir ada tiga. Pertama, zikir dengan hati: Yang Diingat (Mazkur) tidak dilalaikan, demikian pula yang mengingat. Kedua zikir tentang sifat-sifat Yang Diingat, sehingga orang yang berzikir telah melampaui zikir-nya: Sifat-sifat Yang Diingat menyebabkan engkau melampaui sifat-sifatmu sendiri, dan engkau melampaui zikir-mu.

Pandangan yang lebih jernih adalah dikemukakan oleh Rasyid ad-Din Maybudi (w. 520/1126) dalam tafsir Persia awalnya yang terkenal, atau tafsir Alquran, Kasyf al-Asrar. ${ }^{25}$ Dalam menafsirkan QS.3:190-191, ${ }^{26}$ Maybudi menjelaskan tentang hubungan antara kedalaman zikir dengan kebersihan niat dan

\footnotetext{
${ }^{23}$ Ibid, hlm. 610.

${ }^{24}$ Ibid, hlm. 611.

${ }^{25}$ Ibid, hlm. 611.

26 "Sesungguhnya dalam penciptaan langit dan bumi, dan silih bergantinya malam dan siang terdapat tanda-tanda bagi orang-orang yang
} 
keadaan ruhani, dan sebagaimana Sarraj dan Kalabadhi, ia juga menyebutkan pandangannya dalam tiga bentuk: ${ }^{27}$ Menurutnya:

"Ada tiga jenis orang yang berzikir. Orang yang berzikir kepada Allah dengan lisannya sedang hatinya lalai: zikir semacam ini adalah zalim, yang tidak mengetahui apa pun tentang zikir-nya, dan tidak mengetahui apa pun tentang Yang Disebutnya (Mazkur). Orang yang lain berzikir kepada-Nya dengan lisannya yang disertai dengan hadirnya hati: zikir semacam ini adalah zikir 'penuh perhitungan' (muqtasid) yang hanya mencari-cari pahala tetapi pencariannya, namun pencarian seperti ini dibenarkan. Jenis yang ketiga adalah orang yang berzikir kepada Allah dengan hatinya; hatinya dipenuhi dengan Allah, dan lisannya tidak mengucapkan apa pun:'Orang yang mengenal Allah lisannya diam." Inilah zikirnya; karena zikir adalah rahasia dari Yang Disebut (Mazkur), hatinya berada dalam rahasia Cinta; cinta itu berada dalam rahasia cahaya: Ruh (jan) adalah rahasia dari penglihatan langsung (dari yang Ghaib) ['iyan], dan pandangan langsung itu merupakan hal yang tidak dapat digambarkan"

Syekh Abdul Qadir Jailani mengatakan bahwa ${ }^{28}$ Zikrullah yang hanya diucapkan oleh mulut, merupakan manifestasi dari hati agar tidak melupakan Allah swt. zikir senyap atau zikir hati adalah pergerakan emosi atau perasaan. Zikir hati muncul melalui 'rasa', yaitu, rasa tentang penzahiran keagungan dan keindahan Allah swt. Zikir ruh lahir melalui sinar Nûrullah (cahaya Allah) yang dipancarkan oleh keagungan dan keindahan Allah swt. Zikir peringkat rahasia lahir melalui $z a w q$ yang dirasakan dari hasil melihat rahasiarahasia lahir melalui zawq yang dirasakan dari hasil melihat rahasia-rahasia Allah swt. Zikir peringkat rahasia bagi segala rahasia atau zikir rahasia dalam rahasia membawa kita kepada pengertian ayat ini:

"Di tempat yang disenangi di sisi Tuhan yang berkuasa." (al-Qomar: 55)

Zikir peringkat terakhir ialah zikir Khafiy al-Akhfa', yaitu yang paling dalam dan paling tersembunyi. Ini membawa kita ke peringkat perasaan fana' atau lenyap diri dan perasaan dan berpadu dengan Allah swt.

Pada hakikatnya, tidak seorang pun, kecuali Allah yang mengetahui keadaan seseorang yang telah memasuki peringkat itu, yang di dalamnya terkandung semua ilmu. Di situlah ujung atau penambat segala dan setiap sesuatu. Firman Allah, "Dia mengetahui yang rahasia dan yang lebih tersembunyi." 29

\section{F. Landasan Alquran Tentang Zikir}

Objek segenap ibadah ialah mengingat Allah, dan secara terus menerus mengingat Allah (dzikr) sajalah yang bisa melahirkan cinta kepada Allah serta mengosongkan hati dari kecintaan dan keterikatan pada dunia fana ini. Ajaran Islam paling dasar dan paling penting tersirat dalam syahadat atau "pengakuan keimanan", La ilaha illa Allah, yang berarti "tidak ada tuhan selain Allah" atau "tidak ada objek yang layak dan pantas disembah kecuali Allah. Pernyataan ini tak lain dan tak bukan ialah terus menerus mengingat Allah. Segenap bentuk ibadah lainnya menekankan pentingnya mengingat Allah.

Itulah sebabnya para sufi terkemuka memandang zikir atau mengingat Allah sangat penting untuk membersihkan hati. Hal itu bukanlah pendapat personal mereka, melainkan ditandaskan oleh Alquran dan hadits Nabi. Berikut ini adalah ayat-ayat Alquran yang menekankan pentingnya zikir atau mengingat Allah.

Suci Engkau, maka peliharalah kami dari siksa neraka"(191).

${ }^{27}$ Ibid, hlm. 611

28 Syekh Abdul Qadir Al-Jilani, Rahasia Sufi, terj. Pustaka Sufi, Yogyakarta, 2002, hlm. 98-99.

${ }^{29}$ QS. $20: 7$ 
Wahai orang-orang beriman! Berzikirlah dan ingatlah nama Allah dengan zikir sebanyak-banyaknya. Dan bertasbihlah kepada-Nya di waktu pagi dan petang. ${ }^{30}$

(Yaitu) orang-orang yang mengingat Allah sambil berdiri atau duduk atau dalam keadan berbaring dan mereka memikirkan tentang penciptaan langit dan bumi (seraya berkata): "Ya Tuhan kami, tiadalah Engkau menciptakan ini dengan sia-sia, Maha Suci Engkau, maka peliharalah kami dari siksa neraka. ${ }^{31}$

Berikut adalah penjelasan Ibnu Abbas tentang ayat di atas,

Mengingat Allah diperintahkan dalam setiap keadaan- siang dan malam hari, di darat dan di lautan, selama dalam perjalanan, di saat dalam kelapangan dan kesempitan, di saat sakit dan sehat, secara lahir dan batiniah. ${ }^{32}$

Ayat Alquran:

.... Sungguh mengingat Allah adalah paling penting (dalam kehidupan), .... ${ }^{33}$

Ayat ini sudah cukup untuk menunjukkan pentingnya "mengingat Allah". Selanjutnya, Alquran mengatakan:

Maka ingatlah Aku, pasti Aku akan mengingatmu, ... ${ }^{34}$

Di sisi lain Alquran juga berbicara mengenai orang yang melupakan Allah. Orang yang melupakan Allah sama artinya dengan melupakan diri sendiri. Alquran mengatakan:

Dan janganlah kamu seperti orang yang melupakan Allah, lalu Allah pun membuat mereka melupakan diri mereka sendiri. Mereka itu orang-orang yang fasik. ${ }^{35}$

${ }^{30}$ QS. 33:41- 42.

${ }^{31}$ QS. 3: 191

${ }^{32}$ Mir Valiuddin, Op.Cit., hlm. 90.

${ }^{33}$ QS. 29: 45.

${ }^{34}$ QS. 2: 152.

35 QS. 59: 19.

${ }^{36}$ QS. 43: 36.

${ }^{37}$ QS. 58: 19.

38 Dari pengalaman personal, banyak orang mengatakan bahwa hal ini memang benar, bahwa jika
Dalam pengertian spiritual, sesungguhnya orang yang melupakan diri sendiri sesungguhnya telah tersesat. Alquran mengatakan:

Dan barangsiapa berpaling dari mengingat Allah Yang Maha Pemurah, Kami suruh setan akan menjadi temannya yang akrab. ${ }^{36}$

Tidak mengingat Allah menyebabkan hatinya dikuasai kekuatan-kekuatan jahat. Alquran mengatakan:

Setan telah menguasai mereka, lalu membuat mereka lupa mengingat Allah. Mereka adalah golongan setan. Ketahuilah, sungguh, bahwa golongan setan bakal merugi. ${ }^{37}$

Alquran mengatakan dalam ayat yang lain:

Orang-orang laki-laki yang tiada dilalaikan dari mengingat Allah oleh perniagaan dan jual beli,..

Dari ayat ini, Khwajah Baha'uddin menarik kesimpulan tentang zikir terus menerus mengingat Allah yang, menurut hematnya, adalah "banyak mengingat" Allah atau dzikr katsîr, karena tiada henti dan terus menerus berlangsung; ${ }^{38}$ karena selama berjual beli dan mengadakan berbagai transaksi perdagangan, zikir lisan pun berhenti, dan hanya mengingat Allah secara mental saja yang bisa terus dilakukan dalam hati. Sebagaimana telah dinyatakan, zikir ini juga disebut yâd-dâsyt atau "terus menerus mengingat" Allah.

\section{F. KESIMPULAN}

Inti ajaran yang dikembangkan dalam tarekat selalu berlandaskan Alquran meskipun harus melalui proses penafsiran yang dipaksakan seperti dalam ajaran zikir dan

Anda berzikir, sekalipun ketika Anda "secara tidak sadar" melakukannya, Anda akan menemukan bahwa zikir terus berlangsung dalam diri Anda. Inilah dasar hadits Nabi Muhammad. Istri beliau, 'Aisyah, menuturkan kepada kita bahwa sekalipun mata tertutup, hati beliau sama sekali tidak tidur dan sibuk mengingat Allah. Ada suatu tahap dalam meditasi ketika Anda akan bisa mendengar zikir terus menerus berlangsung. Hanay di permulaan saja Anda mesti mengulang-ulanginya secara sadar", Mir Valiuddin,Op.Cit.,hlm. 93. 
bai'at. Ada tiga jenis orang yang berzikir, yaitu: Orang yang berzikir kepada Allah dengan Pustaka Sufi, Yogyakarta, 2003

lisannya sedang hatinya lalai; Orang yang lain berzikir kepada-Nya dengan lisan disertai dengan hadirnya hati;dan yang ketiga adalah orang yang berzikir kepada Allah dengan hatinya sedangkan lisannya tidak mengucapkan apa pun.

Ketiga jenis zikir ini memiliki landasan qur'ani. Diantara ayat al-Qur 'an yang dijadikan landasan zikir dalam ajaran tarekat adalah: QS 33:41-42, QS. 3:191, QS.29:45, QS 2:152, QS 59:19, QS 43: 36, dan QS 58:19.

\section{G. DAFTAR PUSTAKA}

\section{Al-Quran al-Karim}

Annemarie Schimmel, Dimensi Mistik Dalam Islam, Pustaka Firdaus, Jakarta, 2000

Annemarie Schimmel, Sayap-sayap Jibril; Gagasan Religius Muhammad Iqbal, Lazuardi, Yogyakarta, 2003

Husain Heryanto, dalam pengantar Buku Paradigma Holistik, Dialog Filsafat, Sains dan Kehidupan menurut Sadra dan Whitehead, Penerbit Teraju, Jakarta, 2003

Djohan Effendi, Sufisme: Esensi dan Masa Depan Agama Dalam Esensi dan Masa Depan Agama, (Djohan Effendi, ed.) Pustaka Firdaus, Jakarta, 1993

Haidar Bagir, Buku Saku Tasawuf, Penerbit Arasy, PT. Mizan Pustaka, Bandung, 2005 Waheed Akhtar, Pendekatan Sufi Terhadap Problema Alienasi, Dalam Esensi dan Masa Depan Agama, (Djohan Effendi, ed.) Pustaka Fidaus, Jakarta, 1993

Sachiko Murata\&William C. Chittik, Trilogi Islam; Islam, Iman \& Ihsan, PT. RajaGrafindo Persada, Jakarta, 1997

Sayyid Nur bin Sayyid Ali, Tasawuf Syar'i, Kritik atas Kritik, Penerbit Hikmah, 2003

Agus Yahya dan M. Nawawi Syafi'i (ed.), Mengenal Thariqah; Panduan Pemula Untuk Mengenal Jalan Menuju Allah, Sekretariat Jenderal Idarah Aliyah Jam'iyyah Ahli Al Thariqah Al-Mu'tabarah An-Nahdliyyah bekerjasam dengan C.V. Bina Ilmu, Semarang, 2005

Syekh Khaled Bentounes, Tasawuf Jantung Islam, Nilai-nilai Universal Dalam Tasawuf, 